連載（エクステンディド・アブストラクト）

初心者のための実用表面分析講座「分析現場ですぐに役立つ表面分析のノウハウと知識」

\title{
試料の取り扱いと試料前処理
}

\author{
荒木 祥和* \\ 株式会社日産アーク 機能解析部 構造・反応解析室 \\ T237-0061 神奈川県横須賀市夏島町 1 番地 \\ *araki@nissan-arc.co.jp
}

（2018 年 10 月 17 日受理; 2018 年 11 月 29 日掲載決定）

\section{Sample Handling and Sample Pretreatment}

\author{
Sawa Araki* \\ Function Analysis Department, NISSAN ARC, LTD. \\ 1, Natsushima-cho, Yokosuka, Kanagawa 237-0061, Japan \\ *araki@nissan-arc.co.jp
}

(Received: October 17, 2018; Accepted: November 29, 2018)

\section{1. はじめに}

X 線光電子分光法 (XPS : X-ray Photoelectron Spectroscopy), オージェ電子分光法 (AES : Auger Electron Spectroscopy）また二次イオン質量分析法 (SIMS : Secondary Ion Mass Spectrometry)など の各種表面分析法は, 固体表面の組成, 化学状態, 元素の分布状況を把握するためになくてはならない 分析手法である. 近年, 機器の性能向上や操作性の 簡略化はめざましく, 長期間の安定性も確保されて いる. しかしながら，表面敏感な分析法であるがゆ えに試料の取り扱いや試料前処理が不適切であると, 表面組成や状態は変化し, 本来の姿を捉えることが できない，本稿では得られる結果に対して試料調製 の影響が最小になるよう, 試料取り扱い上の注意点 や効果的な前処理手法について紹介する.

\section{2. 対象となる ISO 規格}

表面分析に関する試料の取り扱いや試料前処理に ついては, 以下の ISO によって規格化されてい る.

- ISO 18116 : Surface chemical analysis - Guidelines for preparation and mounting of specimens for analysis（各手法共通一分析試料の前処 理と取り付けに関するガイドライン)
- ISO 18117 : Surface chemical analysis - Handling of specimens prior to analysis (各手法共通 一分析前の試料の取り扱い)

ただし，これらの規格は手法を厳密に定めている ものではなく, 様々な操作とそれらの注意事項の紹 介が中心となっている。 なお, ISO 18116 (試料前 処理）は表面分析を実際に行う者（分析実施者）に 対しての指針であり，一方の ISO 18117（試料の取 り扱い) は表面分析のサービスを受けるユーザー(依 頼者）に対しての指針となっている.

\section{3. 試料の取り扱い}

\section{1 分析面には極力何も触れさせない}

表面分析の試料の取り扱いで最も注意を払うべき ことは，試料を污染しないことである。「分析面に は何も触れさせない」が表面分析の污染防止の原則 であり, 現状保存が分析の鍵となる.

試料に限らず試料を取り付けるホルダーなど真空 チャンバー内に入れるものはすべて, 素手で触るこ とを避ける。試料を扱う際には清浄な手袋と工具を 利用する. 誤って素手で触った試料の表面は皮脂成 分で厚く被われ, 分析したい本来の表面の情報を得 ることはできない，写真 1 に素手で触った SUS 表 面のSEM 観察結果を示す. 素手で触った後の SUS 


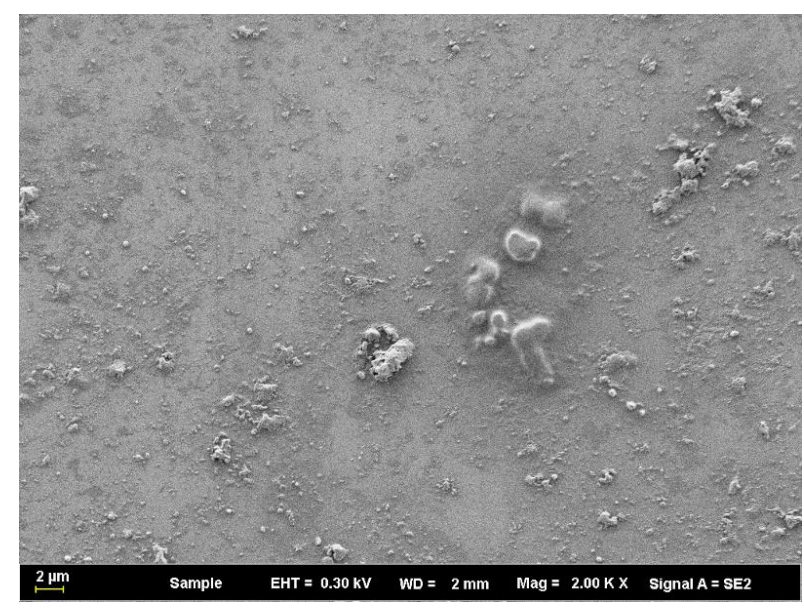

写真 1 素手で触った SUS 表面の SEM 観察結果

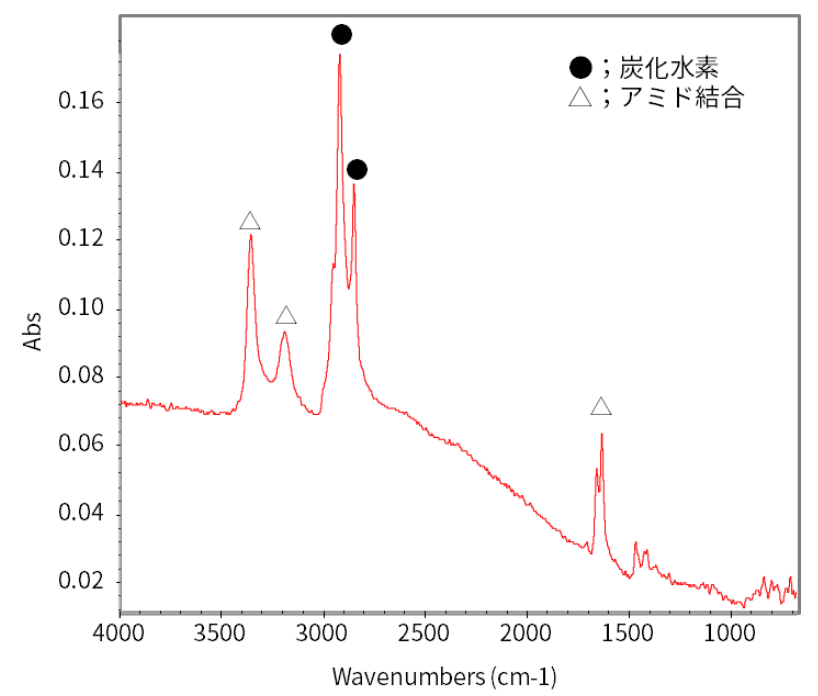

図 1 試料袋内壁に塗布された滑剂の FT-IR スペクトル (color online)

表面は, 元の SUS 表面の切削跡が見えなくなるほ ぞ粒子状の異物が付着しており，このような表面を AES やXPS で分析しても付着物の元素情報しか得 られない。

見た目は清浄に見える樹脂製の試料袋なども，表 面分析の観点から見れば污染源となる. 試料袋内壁 には貼りつき防止のため滑剤が塗布されていること があり, 試料を直接袋に入れると, 試料表面に滑剤 が移着してしまうことがある. 図 1 は，一般的に使 用されるポリエチレン製の試料袋内壁に溶媒を滴下 し, 内壁に存在する有機物を濃縮凝固させて FT-IR 分析を行った結果である. 炭化水素およびアミド結 合に起因するピークが検出され，滑剤として一般的 に使用される脂肪酸アミドであると推測される. (a) Li1s スペクトル
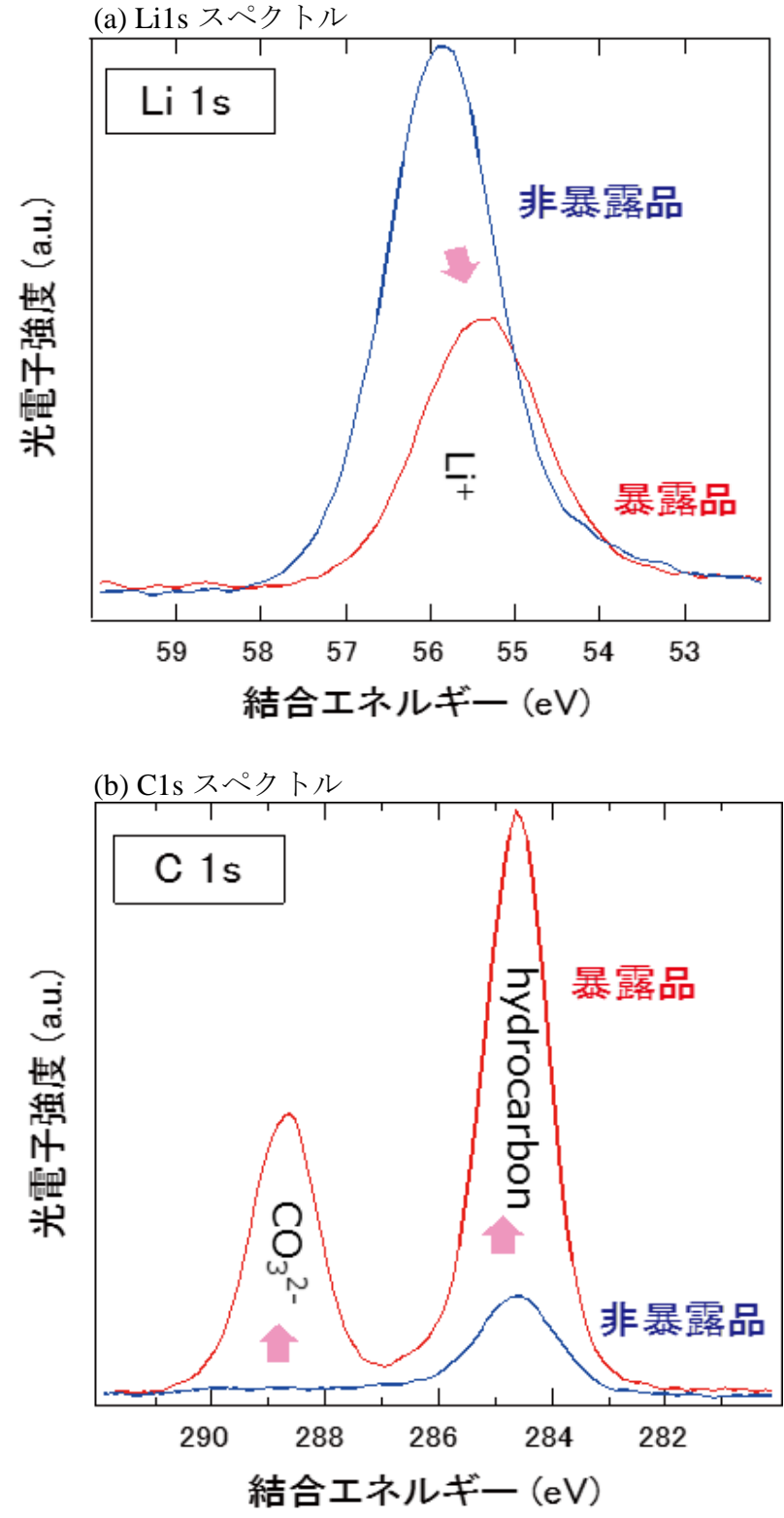

図 2 リチウムイオン二次電池電極表面の大気暴露前後 の XPS スペクトル (color online)

\section{2 試料の保管と運搬}

表面分析を行う試料では，大気による污染や変質 にも気を配る必要がある。その防止には超高真空下 に保管するのが理想的であるが，すべての試料につ いて適用するのは現実的に困難である。一般的には， グローブボックス・真空槽・デシケータなどの制御 された環境下での保管が適当である。雾囲気制御さ れた環境下で作製された試料を大気に触れさせるこ となく分析装置に導入するには, 特殊な密閉容器 （トランスファーベッセル）に試料を格納, 運搬し, 装置の試料導入口に容器をドッキングする. 装置自 体にグローブボックス[1]や特製のガス反応室・熱 
処理室等 [2]を連結させ, 処置後の試料を大気に曝 さずに分析できる装置もある. 図 2 にリチウムイオ ン二次電池電極表面の大気暴露前後の XPS による Li 1s およびC 1s のスペクトル変化を示す. 反応性 の高い $\mathrm{Li}$ 化合物が存在する電極表面は, 大気に触 れると炭酸リチウムの生成と炭化水素の吸着等が起 こってしまう。試料本来の表面を見るためには大気 非暴露で分析・観察する機構が不可欠となる.

以上は理想論を述べたが，既に試料表面が污染さ れている場合も多い. 今日の表面分析は研究分野の みならず, 現象解析や材料解析などのツールとして 重要な役割を果たしている。試料が作動していた環 境は油中や屋外などで, 様々な污染源にさらされて いる。これらの試料は，清浄な環境に保持されてい た試料に比べて取り扱い上の注意は少なくてすむ場 合もあるが, 污染が激しい場合には, 適切な前処理 を施して装置に導入しないと真空チャンバーの污染 につながり, その後の分析にまで影響を及ぼす。分 析依頼者の側にも表面分析での試料の取り扱いを理 解してもらい, 試料の履歴を分析者・依頼者双方で 共有化することが，依頼者の目的を果たすうえで重 要なポイントとなる.

\section{4. 試料前処理}

\section{1 目視確認の重要性}

試料は表面分析装置に導入する前に, 光学顕微鏡 などで試料を目視観察することが望ましい. 分析位 置を確認し, 試料の現状を把握するにはとても重要 な行為である. 分析前に試料の表面状態を把握すれ ば，分析中に起こった変質を見逃すことも少なくな る. 分析に使用する一次励起源によって試料が変質 (損傷）してしまうことがあり，それらを把握した 上でデータ解析するのとしないのでは, 解釈がまる で異なる可能性がある。一般的に試料へのダメージ は, 光 $<\mathrm{X}$ 線 $<$ 電子<イオンの順に大きくなるので, 同一試料を複数の分析にかける場合には, 影響の小 さい順に行うと良い. SEM 観察や EPMA 分析など を行った後の試料は導通確保のための金属蒸着が施 されていたり，それがなくても電子ビームの照射に より特定成分が脱離したり, 装置内のカーボンが吸 着したりすることがあるため気をつける.また, 比 較的損傷が少ないとされる XPS でも, 有機物など の場合には特定の官能基が脱離し, 試料が変質する 場合もある. 分析による変質（損傷）を把握し， そ れを極力避けることが, 試料表面の真の姿を捉える ことにつながる. 表 1 に, 各ポリマーの損傷指数
表 1 各ポリマーの損傷指数

\begin{tabular}{c|c|c|c|c}
\hline 略称 & ポリマー & 指標 & $\begin{array}{c}\text { 損傷 } \\
\text { 指数 }\end{array}$ & $\begin{array}{c}\text { 耐熱温 } \\
\text { 度 }\left({ }^{\circ} \mathrm{C}\right)\end{array}$ \\
\hline $\mathrm{PP}$ & ポリプロピレン & $\mathrm{C} 1 \mathrm{~s} \mathrm{FWHM}$ & 5 & 150 \\
\hline $\mathrm{PS}$ & ポリスチレン & Shakeup/C & 0 & 90 \\
\hline $\mathrm{PBD}$ & ポリブタジエン (cis 型) & Shakeup/C & 60 & 80 \\
\hline $\mathrm{PET}$ & $\begin{array}{c}\text { ポリエチレンテレフタ } \\
\text { レート }\end{array}$ & $\mathrm{O} / \mathrm{C}$ & 0 & 150 \\
\hline $\mathrm{PC}$ & ポリカーボネート & $\mathrm{O} / \mathrm{C}$ & 5 & 120 \\
\hline $\mathrm{PMMA}$ & $\begin{array}{c}\text { ポリメタリリル酸メチ } \\
\text { ルAN }\end{array}$ & $\mathrm{O} / \mathrm{C}$ & 10 & 60 \\
\hline $\mathrm{N} 66$ & ポリアクリロニトリル & $\mathrm{N} / \mathrm{C}$ & 0 & 80 \\
\hline $\mathrm{PTFE}$ & $\begin{array}{c}\text { ポリテトラフルオロ } \\
\text { チレン }\end{array}$ & $\mathrm{N} / \mathrm{C}$ & 5 & 80 \\
\hline $\mathrm{CEL}$ & セ/C & 10 & 180 \\
\hline $\mathrm{CA}$ & セルロースアセテート & $\mathrm{O} / \mathrm{C}$ & 10 & 180 \\
\hline $\mathrm{NC}$ & ニトロセルロース & $\mathrm{N} / \mathrm{C}$ & 65 & 60 \\
\hline $\mathrm{PVA}$ & ポリビニルアルコール & $\mathrm{O} / \mathrm{C}$ & 10 & 60 \\
\hline $\mathrm{PVC}$ & ポリ塩化ビニル & $\mathrm{Cl} / \mathrm{C}$ & 25 & 65 \\
\hline
\end{tabular}

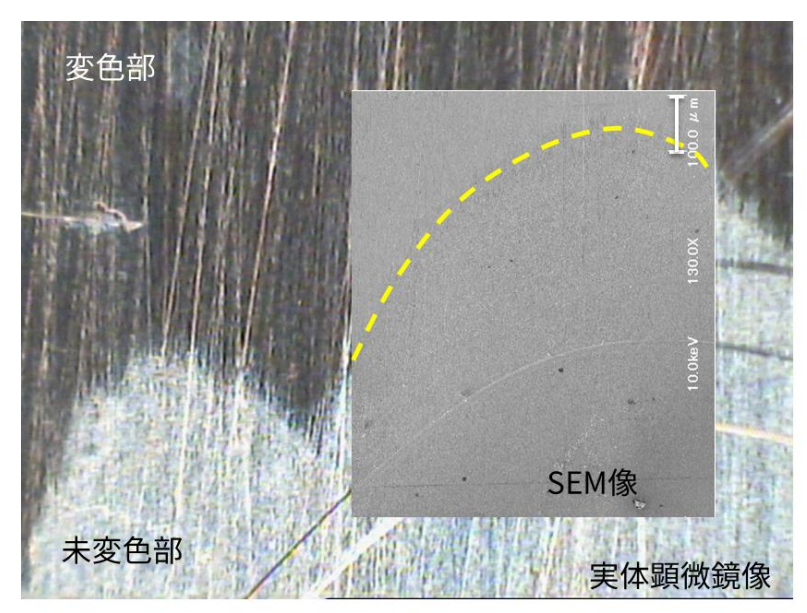

写真 2 変色した $\mathrm{Ag}$ 箔表面の観察結果（color online）

（Degradation Index）[3]および耐熱温度を示す。 なお, 肉眼では変色して見えていても, いざ装置 の中に入れて SEM 観察すると変色部と正常部のコ ントラストがほとんどない，といったことはよくあ ることである. 写真 2 に, 一部黒色化した $\mathrm{Ag}$ 䇴表 面の実体顕微鏡写真と, その一部を SEM で観察し た結果を示す. 分析領域の近くに傷などを付けてマ 一クしておくと, 装置内での分析位置の認識が容易 になる（ただし，マーキングには間違っても油性ぺ ン等污染源となるものを使用しない）。 


\section{2 様々な試料固定方法}

\subsection{1一般的な試料の固定}

試料の形状や特性は様々であり，それを真空チャ ンバー内に導入するために各装置には様々な形の試 料ホルダーが準備されている.より大型の試料や多 数の試料を一度に装着できるようなホルダーを備え る装置もあり, $300 \mathrm{~mm}$ ウェハをそのまま導入する 専用ホルダーも市販されている.

最も一般的な試料の取り付けは，ネジや金属製押 さえ板を用いて固定する方法である，この場合，測 定領域が押さえ板の空から広く露出寸るようにし, また, 測定領域に対して, 固定器具や試料自身が装 置内で入射系・検出系経路の立体障害にならないよ うに注意する。

\subsection{2 小さな試料の固定}

試料表面に，測定領域以外に押さえる余地のない 小さな試料は, 真空対応の導電テープで裏面をホル ダーに接着したり，In などのやわらかい金属箔に 埋め込んだりする手法もとられる.XPS ではどち らの手法も有効であるが, AES では導電テープで は十分な導通が取れない場合も多いのでやわらかい 金属馢を推奨する.In などの金属箔は, 試料を付 ける前に表面を擦って新生面を出しておくと, 粘着 性が高まって試料との密着性が良くなる.

\subsection{3 線状試料の固定}

線状試料の表面を測定する場合, 試料の直径と入 射ビームの径に気をつけて試料を固定する. 具体的 には, 試料の直径く入射ビームの径となると下地で あるホルダーの情報を取り込むため, 試料を十分準 備できる場合には並べたり束ねたりして下地を隠す。 また少量しか準備できない場合には，中央が凹型に 窪んだホルダーを用いて, 試料をそこに渡すように 固定し, 単色化したX線源を利用する. 単色化した $\mathrm{X}$ 線源は検出焦点が合っていないと光電子の強度が

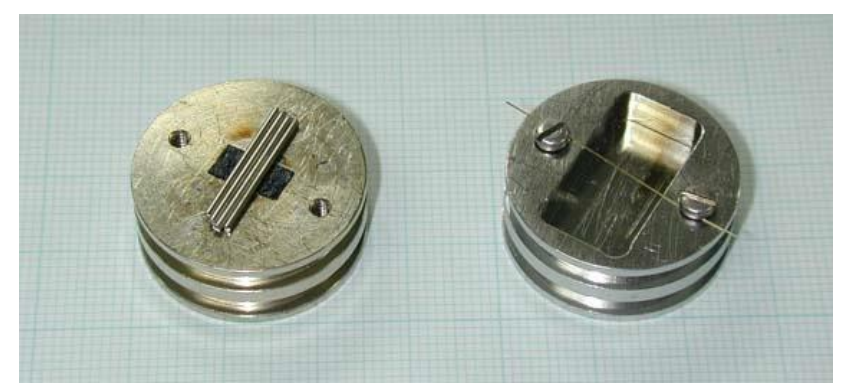

得られないため，凹型の底に入射ビームが照射され たとしてもホルダー成分は検出されない. 写真 3 に, 線状試料を並べて固定した場合（視野左）と凹型に 嵀んだホルダーに線状試料を橋渡しして固定した場 合（視野右）をそれぞれ示す。

\subsection{4 粉末試料の固定}

粉末試料は, 真空排気や大気開放の際に予備排気 室内へ飛散したり，固定が不十分だと真空チャンバ 一内に脱落したりするので, 他の形態に比べて取り 扱いには注意を要する．前述の金属箔や導電テープ 上に分散させ，押しつけて固定する手法が簡便でよ く使われる，金属䇴，導電テープとも，下地が見え ない十分な量の粉末を置き, 薬包紙などを挟んで硬 い金属で押さえつけた後，余分な粉をエアブローで 除去する. 深さ方向分析の際にイオンエッチングを 行うと, In が測定面に再付着することがあるので In の露出は少ない方が良い. 試料を多量に準備で きる場合には, 赤外分光法などで $\mathrm{KBr}$ をディスク 状に成形する加圧器を用いてペレット化すると, 通 常の板状試料之同様に扱える。試料が絶縁性の場合, この方法は取り扱いが容易になるうえに試料表面の 平滑性が向上し，XPS を測定する際スペクトル強 度や帯電中和の観点で有利にもなる。ただし, 加圧 時の圧力や温度上昇, 金型表面の清浄度には気をつ けなければならない。

最近では, ヤモリの足の接着機構を, 高密度に垂 直配向させた CNT（カーボンナノチューブ）により 再現し，試料を固定できるテープ（日東電工製ヤモ リテープ）も市販されている。このテープを用いる と, 従来の導電テープでは問題となっていた真空中 でのアウトガスやドリフト等を抑えた分析が可能で ある。

\subsection{5 絶縁物試料の固定}

試料の特性，特に導電性の有無によっても試料の 固定方法に工夫が必要となる. 絶縁物の測定では, 試料表面が正または負に帯電し, 正常なスペクトル 測定の妨げとなる $[4,5]$. 絶縁物試料を固定する場 合には, 測定領域の周辺を導通があるもので覆い, 被覆物と試料ホルダーの導通を確実にとることが比 較的簡便で有効である。この方法は熱を周囲に逃が し，熱による変質を防止するという観点でも有効で ある。

写真 3 線状試料の固定方法 (color online) 
絶縁物試料の測定では, 試料の固定方法のみで十 分な導通を確保することが難しい場合も多いため, 試料前処理を工夫するとともに, 装置に付属する帯 電中和機構を併用するとよい.

\section{3 各種の前処理技術}

\subsection{1 污れの除去}

前述のとおり, 表面分析では試料表面を污さず, 元の状態を保つことが試料の状況を把握するために 欠かせないが，時にはその污れの下に存在する本来 の表面を露出させることも必要となる. 污れ除去の 方法には,

・エアブロー（工場の供給ラインガスは污染されて いる可能性があるので注意が必要）

・洗浄（目的物質を洗い流さない溶媒, 極性を考え る)

・イオンスパッタリング

・プラズマエッチング

・紫外線照射

・加熱

等がある.このうちイオンスパッタリングは，現 在市販されている装置にはほぼ標準装備されている $\mathrm{Ar}$ イオンをイオン源とすることが最も一般的であ るが, 最近ではよりダメージが少ないクラスターイ オン源 ( $\mathrm{C}_{60}, \mathrm{PAH}$ : Polycyclic Aromatic Hydrocarbon, Ar2500 クラスター等）もオプション 等で装備できるようになっている，ただし，上記に 挙げた手法はいずれも試料表面を劇的に変化させる 可能性があるため, 試料履歴や分析の目的を考えた うえで使用する.

\subsection{2 断面化技術}

断面を作製することで，表面からではわからない 試料内部の広範囲な元素分布を把握することが可能 となる．断面化技術としては樹脂包埋後に研磨によ り断面作製する手法が最も汎用的であるが，超高真 空装置に埋め込み樹脂を導入すると, そこからガス が出て分析面に再付着し, 試料の情報が得られなく なるばかりか装置内も污染する。ややを得ず埋め込 み樹脂ごと試料を装置に導入する場合は, できるだ け埋め込み樹脂の不要な部分をカットしてから装置 に導入するとよい. また, Gaイオンにより $0.1 \mu \mathrm{m}$ 未満の位置精度で狙った位置を加工できる集束イオ ンビーム（FIB : Focused Ion Beam）やArイオン を用いて FIB よりも広範囲に断面を作製できるク ロスセクションポリッシャー (CP : Cross Section

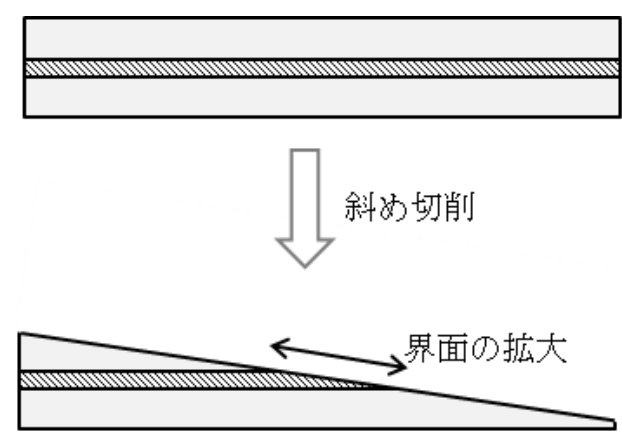

図 3 サイカスによる斜め切削

Polisher）等，イオンビームによる加工装置も近年 普及してきている.

さらに, サイカス (SAICAS : Surface and Interfacial Cutting Analysis System) という本来 は被着体の剥離強度やせん断強度を測定する装置を 用いて, 図 3 に示すように積層膜を斜め切削し, 界 面幅を広げて表面分析に適用する試みも行われてい る.

\subsection{3 帯電を低減する前処理}

絶縁性物質を試料とした場合, 帯電により分析が 困難となることがある。特に, AES は励起源・検 出量子とも電子であり, その傾向が強い, 帯電を低 減するための各種のテクニックは ISO 29081(AES 向け)やISO 19318 (XPS 向け) に紹介されている. たとえば, 試料の薄片化, 蒸着, FIBによる配線等 が挙げられる.

\section{5. おわりに}

今回は割愛したポイントも多く, より詳細な解説 は試料取り扱いの総説[6]や出版されている表面分 析関連の書籍 $[7,8,9]$ を参照されたい. 適切な試料の 取扱いや前処理を行い, 試料本来の姿を捉えて研究 開発や不具合調查に表面分析をさらに活用していっ ていただければ幸いである。

\section{6. 参考文献}

[1] 黒河明, J. Surf. Anal., 6, 285 (1999).

[2] 宗像文男, 御園康仁, 志智雄之, 谷村誠, 北村 勇, 小山博之, 井上靖秀, 秋宗淑雄, 表面科学, 19, 294 (1998).

[ 3] G. Beamson and D. Briggs, "High Resolution XPS of Organic Polymers", Wiley (1992).

[4] 楠神久人, 福島整, 電子材料グループ, J. Surf. 
Anal., 2, 423 (1996).

[ 5] 武内豊, J. Surf. Anal., 2, 442 (1996).

[6] 當麻肇, J. Surf. Anal., 7, 27 (2000).

[7] 志水隆一, 吉原一紘 編, ユーザーのための実用 オージェ電子分光法, 第 4 章, pp. 61-68, 共立出 版 (1989).

[8] 山科俊郎, 福田伸, 表面分析の基礎亡灾用, 第3 章, pp. 27-30, 東京大学出版会 (1991).

[9] 橋本哲, 表面分析技術選書オージェ電子分光法, 日本表面科学会 編, 第 2 章, pp. 7-16, 丸善 (1998).

\section{査読コメント，質疑応答}

\section{查読者 1. 高橋 直子（豊田中央研究所）}

測定者にとって直接的に役立つ，有意性の高い記 事だと思いました。執筆者の幅広い知見に敬意を表 します, 以下について対応頂けますと, 特に初心者 に対してはより理解し易くなると思いましたので, ご検討頂ければ幸いでございます。

\section{[査読者 1-1]}

写真 1 について

実際にコンタミが付着した様子を示す貴重な写真 と思います。故に，付着前に対してどのように異な るかが不明で寸ので，触る前の写真をお示し頂くか， 本文中に具体的に表現して頂けると有難いです（素 手で触った後は切削跡が見えず一様?, 粒子状のも のが付着？等）。

\section{[著者]}

付着前の写真が残っていないため,「素手で触っ た後の SUS 表面は，元のSUS 表面の切削跡が見え なくなるほど粒子状の異物が付着しており，このよ うな表面を AES やXPS で分析しても，付着物の元 素情報しか得られない。」の一文を追記いたしまし た.

\section{[查読者 1-2]}

図 2 について

Li1s は非暴露品のどのような化学状態から暴露 品の炭酸リチウムへ変化したのか, 帰属が記載され ていると理解し易いです．また， C 1s は炭酸塩の ピークだけでなく炭化水素（?）のピーク強度も高 くなっていますので, 大気に触れると炭酸リチウム の生成と炭化水素の吸着が起こる旨を記載してはい かがでしょうか?

\section{[著者]}

図一の帰属追記と，「電極表面に存在する反応皮 膜は，大気に触れると瞬時に炭酸リチウムが生成し てしまう」の一文を, 「反応性の高い $\mathrm{Li}$ 化合物が存 在する電極表面は, 大気に触れると炭酸リチウムの 生成と炭化水素の吸着等が起こってしまう。」と修 正いたしました. 


\section{查読者 2. 佐藤 美知子（東京工業大学）}

表面分析を行うための試料の取り扱いと前処理に ついて，実例も交えて分かりやすく説明されており， 分析実施者と分析依頼者にとって有用な情報を提供 しています．本誌に掲載すべきものと考えます．こ のままで掲載されても良いと思いますが，もしかし たら誤解されるかもしれないと思われた箇所を挙げ ますので, ご検討ください.

\section{[查読者 2-1]}

\section{2 試料の保管と運搬}

「電極表面に存在する反応皮膜は，大気に触れる と瞬時に炭酸リチウムが生成してしまう。」 ）「炭酸リチウムへと変化してしまう。」あるい は「その表面に炭酸リチウムが生成してしまう。」 とした方が良いかと思います。

\section{[著者]}

もう 1 名の査読者の方からもご指摘いただき, 「反応性の高い $\mathrm{Li}$ 化合物が存在する電極表面は, 大気に触れると炭酸リチウムの生成と炭化水素の吸 着等が起こってしまう。」と改めました.

\section{[査読者 2-2]}

「実情は試料を清浄に保つことが困難な場合も多 い. 」

＼cjkstart意味するところは, 試料採取の時点で既に本来 の表面が表れていないということだと思います。こ こは「既に試料表面が污染されている場合も多い.」 あるいは「試料表面が既に清浄な状態になっていな い場合も多い。」などとした方が，違和感がないよ うに思います。

\section{[著者]}

ご指摘のとおり，「既に試料表面が污染されてい る場合も多い.」に改めました。

\section{[查読者 2-3]}

\section{1 目視確認の重要性}

「たとえば」であげた例は目視確認しただけでは 分からないことであり，「4.2 分析中の試料損傷」 の冒頭の文章が, むしろ目視確認の重要性を説いて いるように思えます。この二つの章は分けずに, 試 料損傷の説明の中で試料導入前の目視確認の重要性 を説き,「なお，肉眼では変色して見えていても，
いざ装置の中に入れて SEM 観察すると…とした 方が，流れが良いと思います。

\section{[著者]}

ご指摘のとおり， 4.1 目視確認の重要性と 4.2 分析中の試料損傷を統合し, 以降の章番号を修正い たしました。 